\title{
Fungi isolated from Niedźwiedzia Cave in Kletno (Lower Silesia, Poland)
}

\author{
Rafał Ogórek ${ }^{1 *}$, Agnieszka Lejman ${ }^{2}$, and Krzysztof Matkowski ${ }^{1}$ \\ ${ }^{1}$ Wrocław University of Environmental and Life Sciences, Department of Plant Protection, Division of Plant Pathology and Mycology, Poland \\ ${ }^{2}$ Wrocław University of Environmental and Life Sciences, Department of Agroecosystems and Green Areas Management, Poland
}

\begin{abstract}
Niedźwiedzia Cave is the most beautiful cave in Poland, discovered in a block of Cambrian marbles. It is the most important part of the reserve established in 1977. The cave is located within the Kłodzko Valley, in Śnieżnik Mt. Massif, in Kleśnica Stream Valley and was discovered in 1966 while working in a quarry. The study aimed at first mycological evaluation of the air and the rocks in Niedźwiedzia Cave. Nine species of filamentous fungi and a yeast species were isolated from the air sampled in the cave, whereas from the rocks - nine species of filamentous fungi and two species of yeasts were collected. Rhizopus stolonifer was the species most frequently isolated from the air and from the rocks, while the least isolated from the air was Sclerotinia sclerotiorum. Among the species found in the rock, the least frequently collected were Fusarium oxysporum and the yeast Rhodotorula rubra.
\end{abstract}

Keywords: Niedźwiedzia Cave; fungi; yeasts; air; rocks

Received 30 March 2013; Revised 21 May 2013; Accepted 22 May 2013

Citation: $\quad$ Ogórek R., Lejman A. and Matkowski K., 2013. Fungi isolated from Niedźwiedzia Cave in Kletno (Lower Silesia, Poland). International Journal of Speleology, 42 (2), 161-166. Tampa, FL (USA) ISSN 0392-6672 http://dx.doi.org/10.5038/1827-806X.42.2.9

\section{INTRODUCTION}

Cave ecosystems are very specific and they are different from other ecosystems in that they experience relatively stable low temperatures and that they are nutrient-poor biotopes (Poulson \& White, 1969; Barton \& Northup, 2007). The making a cave available to visitors can result in changes in its microclimatic conditions. Tourists can contribute to increase in air temperatures, $\mathrm{CO}_{2}$ concentration (Hoyos et al., 1998) and they can serve as a source of organic matter and new microorganisms. All the listed factors may contribute to the growth of microbial flora in a cave (Ogórek, 2012). Among numerous biological agents, fungi and bacteria play a critically important role in stone deterioration, e.g. by biofilm formation and by their physical penetration into the substrate. They can produce secondary metabolites, which may cause chemical reactions with the substrate and contamination of the substrate by pigments (Gu, 2003; Li et al., 2008). However, fungi are an important part of cave mycobiota, because they play an important role in the feeding strategies of cave fauna among other decaying organic material (Nováková, 2009).

There are reports in the literature about fungi isolated from the air of caves, cave rocks, sediments and biota present in the caves (Gunde-Cimerman et al., 1998;
Nieves-Rivera et al., 2009; Nováková, 2009; Bastian et al., 2010; Jurado et al., 2010; Wang et al., 2010; Trigo et al., 2011). Depending on the isolation place, the composition of fungi species is different. Bats and arthropods can bring secondary fungi to a cave. For example, many scientists reported strong correlation between cave fungi and arthropods (Kubátová \& Dvorák, 2005; Jurado et al., 2008), because a lot of fungal species are entomopathogenic taxa (Samson et al., 1988).

Nováková (2009) reported that ca. 69 genera of fungi can be isolated from the air, flora and fauna of the caves in Slovakia. Most of them were fungi such as Aspergillus spp. and Penicillium spp. Among these fungi, species can be found which are causing serious diseases, as well as those being allergens in humans. The first group includes such fungi as Aspergillus spp. (aspergillosis of the lungs, sinuses, cornea, orbit, skin, nails, and of ear canal), Rhizopus spp. (mucormycosis of lungs, sinuses and generalized) and Fusarium spp. (generalized fusariosis) (Adamski et al., 2008a, b). The second group is the microbial agents causing allergies. The fungi classified above, in the first group, belong here as well, but apart from them there are also such taxa as Alternaria spp., Acremonium spp., Cladosporium spp. and Penicillium spp. (Adamski et al., 2008c). 
DESCRIPTION OF STUDIED CAVE

Niedźwiedzia Cave in Kletno is the most important part of the reserve established in 1977. The cave is located within the Kłodzko Valley, in Śnieżnik Mt. Massif, in Kleśnica Stream Valley, and was discovered in 1966 while working in a quarry. Its geographic coordinates are $50^{\circ} 14,068^{\prime} \mathrm{N}$ and $16^{\circ} 50,558^{\prime} \mathrm{E}$, and its entrance is located $800 \mathrm{~m}$ a.s.l. The length of its currently known corridors is $>3 \mathrm{~km}$ (Pulina, 1970, 1989).

The cave complex includes three levels: the upper, the middle and the lower, connected by chimneys. The middle level is partly developed for visitors. The trail starts at the entrance, which is the air lock, and then leads to the Great Fissure. It passes the bridge over the Great Fissure, the Step Chamber, and the concrete corridor and reaches the Rice Threshold. The stairs take the visitors to the Lions' Hall, which is filled with the internal, rubble-clayey sediments full of bones of Pleistocene fauna. Later the visitors move through the corridor dug in the sediments pile and walk upstairs, into the chamber named the Bivouac, located at the crossing of two corridors: one heads southwest, towards the exit, and the second heads south, to the Sinter Pools Corridor. From the Bivouac it is possible to move through the corridor dug in rock to the Stalactite Corridor, which passes into Palace Hall. From there, the northeast-heading gallery takes the tourists to the Cascade Lane, where there is the entrance to the upper level. From the Palace Hall the corridor leads to the western end, passing by the southeastern entrance to the Hall of Sinter Pools and continues along the artificial gallery to the Primitive Man`s Corridor. It then leaves the cave through the Exit Gallery facilitated with the system of air locks (Pulina, 1996).
Niedźwiedzia Cave is a habitat that has been in the past and is currently inhabited by living organisms (Wiszniowska, 1967, 1989). Samples mined from the cave's sediments contain hundreds of thousands of debris fragments, consisting of vertebrate bones and shells of snails. These allowed to detecting the presence of, inter alia, remains belonging to 29 species of mammals and shells of snails (29 species). The contemporary living fauna in the cave is represented by springtails, spiders, insectivores, bats and rodents (Bieroński et al., 2007).

\section{MATERIAL AND METHODS}

The samples were taken on the 5 May 2012 from 3 locations inside Niedźwiedzia Cave: Lion`s Hall, The Palace Hall, and Primitive Man`s Corridor (Fig. 1).

\section{Mycological evaluation of the air}

To examine the air, PDA medium (Potato Dextrose Agar, Biocorp) was used. The sampler (Air Ideal 3P) was programmed for the air sample volumes of $50 \mathrm{~L}$, $100 \mathrm{~L}$ and $150 \mathrm{~L}$. Measurement in particular locations was performed in six-plicate for each volume. The sampler was positioned $1.5 \mathrm{~m}$ above the level of the cave floor. The incubation of the cultures on Petri dishes of $90 \mathrm{~mm}$ diameter was carried out at room temperature $\left(22^{\circ} \mathrm{C}\right)$ for $2-7$ days, in the darkness. After the incubation the number of $\mathrm{CFU} / 1.0 \mathrm{~m}^{3}$ (Colony Forming Unit per $1.0 \mathrm{~m}^{3}$ of air) was calculated and the fungi were identified.

\section{Microbiological evaluation of the rocks}

Mycological evaluation of the rocks in Niedźwiedzia Cave was performed using three methods.

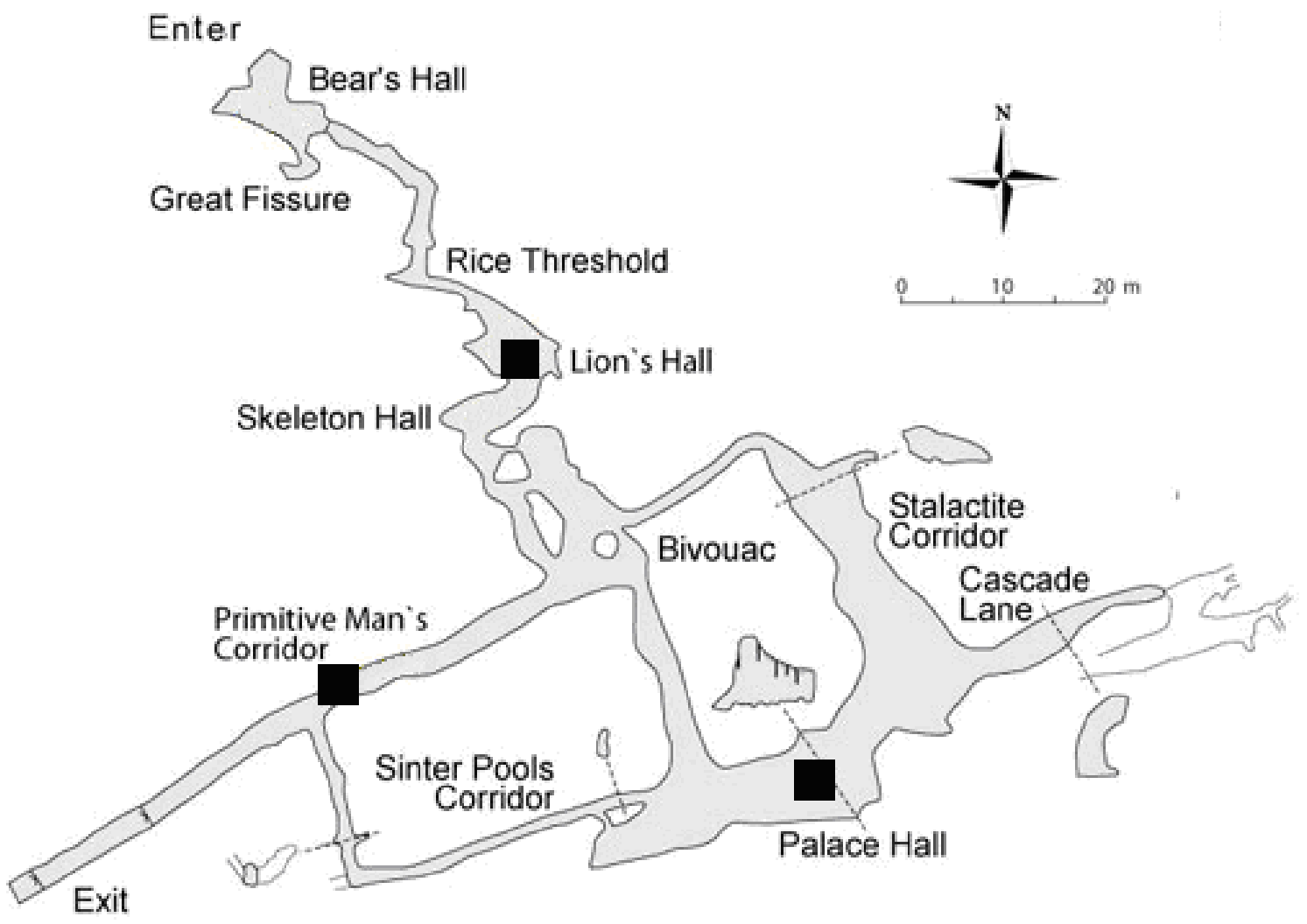

Fig. 1. Sampling location (Lion's Hall, Palace Hall and Primitive Man's Corridor) from the middle levels of Niedźwiedzia Cave. 


\section{Debris sampling procedure.}

Rock debris ( $1-3 \mathrm{~cm}$ in length) were collected using the forceps from three locations in Niedźwiedzia Cave and placed into sterile sampling bags (114 x $229 \mathrm{~mm})$. On the same day the rocks were placed on Petri dishes with the solidified PDA medium (Biocorp). From every research location 25 rocks were collected. The incubation of cultures on Petri dishes of $90 \mathrm{~mm}$ diameter was carried out at room temperature $\left(22^{\circ} \mathrm{C}\right)$ for 2-7 days in the darkness. After the incubation, the number of CFU per 25 rocks was calculated and the fungi were identified.

\section{Swab sampling procedure.}

Swabs were made using sterile swabs in transport tubes (plastic applicator, viscose swab, of $15 \mathrm{~cm}$ length). Material from every location was sampled with three swabs, from the surface area of $1.0 \mathrm{~cm}^{2}$ and $5.0 \mathrm{~cm}^{2}$. The samples were taken from the cave floor and from its walls at the height of $1 \mathrm{~m}$ and $2 \mathrm{~m}$ above the floor. On the same day, the collected samples were shaken for 20 minutes in 50-ml Erlenmeyer flasks containing $10 \mathrm{ml}$ of sterile distilled water. After shaking, the samples were placed in a Petri dish, on the solidified PDA medium, using serial dilution technique. The incubation of cultures on a Petri dishes of $90 \mathrm{~mm}$ diameter was carried out at room temperature $\left(22^{\circ} \mathrm{C}\right)$ for 2-7 days in the darkness. After the incubation, the number of CFU per $1.0 \mathrm{~cm}^{2}$ rock surface and the fungi were identified.

\section{Rinse sampling procedure.}

From every location 6 samples of rock debris were collected using the forceps to sterile sampling bags (114 x $229 \mathrm{~mm})$. On the same day, each sample (ca. $30 \mathrm{~g}$ ) was shaken for 20 minutes in a 250-ml Erlenmeyer flask containing $100 \mathrm{ml}$ of sterile distilled water. After shaking, the samples were placed in a Petri dish, on the solidified PDA medium by using serial dilution technique. The incubation of cultures on Petri dishes of $90 \mathrm{~mm}$ diameter was carried out at room temperature $\left(22^{\circ} \mathrm{C}\right)$ for 2-7 days in the darkness. After the incubation, the fungi were identified.

\section{Fungal identification}

After incubation $\left(22^{\circ} \mathrm{C}, 2-7\right.$ days, in the darkness), the fungal colonies grown on each one of the Petri dishes of $90 \mathrm{~mm}$ diameter were counted and identified. The specific identification of the sampled fungi was performed using macro- and microscopic observations, namely the morphology of hyphae, conidia and sporangia, of the colonies that had grown on culture media, according to the commonly accepted methods used in mycological laboratories. The fungi were identified using diagnostic keys (Raper \& Fennell, 1965; Raper \& Thom, 1968; Ellis, 1971).

\section{Media}

The following media were used: Potato Dextrose Agar (PDA, Biocorp), Czapek-Dox Agar (1.2\% agar, Biocorp) and Malt Extract Agar (MEA, Biocorp). PDA medium and acidified PDA medium were used for the isolation of fungi from the air and the rocks and for the identification of some species. Czapek-Dox agar medium and MEA medium were used for identification of the Penicillii and Aspergillii.

\section{RESULTS AND DISCUSSION}

The content of microorganisms in the environment depends on many factors, inter alia on the geographical location of a habitat, and on the season of the year. However, the most important factors are the air temperature and humidity (Kaiser, 2005). The average annual air temperature and humidity in Niedźwiedzia Cave amounted to ca. $6^{\circ} \mathrm{C}$ and $98 \%$ (Table 1). The air humidity in the cave was conducive for the survival and development of fungi, while the air temperature, although facilitating their survival, was not much contributory to their development (except Cladosporium spp.). The content of fungi in the cave is probably determined by other factors such as airflow system in the cave, arthropods, bats or visitors, which can bring secondary fungi to the cave (Hoyos et al., 1998; Gu, 2003; Kubátová \& Dvorák, 2005; Jurado et al., 2008; Li et al., 2008; Voyroni et al., 2011).

Thirteen species of filamentous fungi and two species of yeasts were isolated from Niedźwiedzia Cave. Nine species of filamentous fungi and one yeast species were isolated from the air sampled in the cave, whereas from the rocks - nine species of filamentous fungi and two species of yeasts were collected (Table 2). The fungi such as Beauveria bassiana, Cladosporium herbarium, Penicillium expansum and Sclerotinia sclerotiorum were present only in the air, whereas Fusarium oxysporum, Fusarium graminearum, Mucor mucedo, Trichoderma harzianum and the yeast Rhodotorula rubra were present only on the rocks. The observed differences in species composition of fungi between the air and the rocks in the cave may be the artifacts caused by imprecision of the testing methods used, or by the physiology of

Table 1. The average annual temperature and air humidity in Niedźwiedzia Cave in Kletno - 2012.

\begin{tabular}{|c|c|c|}
\hline $\begin{array}{c}\text { Location of } \\
\text { measurement }\end{array}$ & Air temperature $\left[{ }^{\circ} \mathrm{C}\right]$ & Relative humidity of air [\%] \\
\hline Lion's Hall & 6.29 & $98.0 \%$ \\
\hline The Palace Hall & 6.16 & $98.1 \%$ \\
\hline Primitive Man's Corridor & 6.08 & $98.0 \%$ \\
\hline
\end{tabular}

Table 2. Filamentous fungi and yeasts isolated from the air and the rocks of Niedźwiedzia Cave in Kletno.

\begin{tabular}{|l|c|c|}
\hline \multicolumn{1}{|c|}{ Taxa } & Air & Rock \\
\hline Acremonium strictum W.Gams & $+^{*}$ & + \\
\hline Aspergillus niger group & + & + \\
\hline Beauveria bassiana (Bals.-Criv.) Vuill. & + & - \\
\hline Candida albicans Berkhout & + & + \\
\hline Cladosporium herbarum Pers. & + & - \\
\hline Fusarium oxysporum Schltdl. & - & + \\
\hline Fusarium graminearum Schwabe & - & + \\
\hline Mucor mucedo de Bary \& Woron & - & + \\
\hline Penicillium chrysogenum Westling & + & + \\
\hline Penicillium expansum Link & + & - \\
\hline Rhizopus stolonifer (Ehrenb.) Vuill & + & + \\
\hline Rhodotorula rubra (Schimon) F.C. Harrison & - & + \\
\hline Sclerotinia sclerotiorum (Lib.) de Bary & + & - \\
\hline Ulocladium alternariae (Cooke) E.G. Simmons & + & + \\
\hline Trichoderma harzianum Rifai & - & + \\
\hline$\sum$ species & 10 & 11 \\
\hline *+ species present; -species absent & & \\
\hline
\end{tabular}


the isolated fungi (sporulation, secretion of secondary metabolites). For example, fermentative microorganisms excrete many organic acids into the environment, including the lactic, acetic and butyric acids, which may cause biodeterioration of natural stones, as well as brick, concrete or mortars. Fungi of the genus Fusarium belong to this group of microorganisms. (Gu et al., 1998; Cwalina, 2008).

Most of the fungi and yeasts from the air and the rocks were isolated from the Lion's Hall and the least - from the Primitive Man`s Corridor (Table 3, 4, 5). The Lion's Hall is the first location of research and is located closest to the entrance to the cave, while the Primitive Man's Corridor is the last location of research and is located closest to the exit to the cave. The abundance of the fungi decreases from the entrance towards the exit of the cave. Such situation is probably caused by the airflow, which occurs in the cave during the summer, or by the tourist traffic. Pflitsch and Piasecki (2003) reported that behind the entrance to the cave, different processes, anthropogenic and natural, may alter the air circulation. During the summer season, a permanent stream of the warm external air flows next to the cave entrance area, and the air from the outside is conveyed to the inside of the cave. The air flow can transfer fragments of fungal mycelia and spores.

Rhizopus stolonifer was the most frequently isolated fungus from the air and the rocks, while the least isolated from the air was Sclerotinia sclerotiorum and from the rock - Fusarium oxysporum and the yeast Rhodotorula rubra (Table 3, 4, 5, 6). Rhizopus stolonifer is omnipresent as a saprophyte and sometimes as a weak parasite on stored organs (Agrios, 1997). It is the causal agent of rhizopus rot disease of various plants and this fungus commonly causes postharvest diseases on many plants. Rhizopus stolonifer causes a soft, watery rot, and

Table 3. Filamentous fungi and yeasts isolated from the air of Niedźwiedzia Cave in Kletno.

\begin{tabular}{|c|c|c|c|c|}
\hline \multirow{2}{*}{$\begin{array}{l}\text { Location of } \\
\text { measurement }\end{array}$} & \multirow{2}{*}{ Fungi or yeast species } & \multicolumn{2}{|c|}{ Air - CFU/m3 } & \multirow{2}{*}{$\begin{array}{l}\text { Species } \\
{[\%]}\end{array}$} \\
\hline & & Species & $\begin{array}{l}\text { In } \\
\text { total }\end{array}$ & \\
\hline \multirow{6}{*}{ Lion's Hall } & Aspergillus niger group & 1 & \multirow{6}{*}{232} & 0,4 \\
\hline & $\begin{array}{l}\text { Beauveria bassiana } \\
\text { (Bals.-Criv.) Vuill. }\end{array}$ & 60 & & 25,9 \\
\hline & Cladosporium herbarum Pers. & 40 & & 17,2 \\
\hline & Penicillium chrysogenum Westling & 30 & & 12,9 \\
\hline & Rhizopus stolonifer (Ehrenb.) Vuill & 100 & & 43,1 \\
\hline & $\begin{array}{l}\text { Sclerotinia sclerotiorum } \\
\text { (Lib.) de Bary }\end{array}$ & 1 & & 0,4 \\
\hline \multirow{8}{*}{$\begin{array}{l}\text { The Palace } \\
\text { Hall }\end{array}$} & Aspergillus niger group & 1 & \multirow{8}{*}{193} & 0,5 \\
\hline & $\begin{array}{l}\text { Beauveria bassiana } \\
\text { (Bals.-Criv.) Vuill. }\end{array}$ & 15 & & 7,8 \\
\hline & Candida albicans Berkhout & 10 & & 5,2 \\
\hline & Cladosporium herbarum Pers. & 20 & & 10,4 \\
\hline & Penicillium chrysogenum Westling & 20 & & 10,4 \\
\hline & Penicillium expansum Link & 15 & & 7,8 \\
\hline & Rhizopus stolonifer (Ehrenb.) Vuill & 109 & & 56,5 \\
\hline & $\begin{array}{l}\text { Ulocladium alternariae (Cooke) } \\
\text { E.G. Simmons }\end{array}$ & 3 & & 1,6 \\
\hline \multirow{4}{*}{$\begin{array}{l}\text { Primitive } \\
\text { Man's } \\
\text { Corridor }\end{array}$} & Acremonium strictum W.Gams & 10 & \multirow{4}{*}{140} & 7,1 \\
\hline & Aspergillus niger group & 10 & & 7,1 \\
\hline & Cladosporium herbarum Pers. & 50 & & 35,7 \\
\hline & Rhizopus stolonifer (Ehrenb.) Vuill & 70 & & 50,0 \\
\hline
\end{tabular}

Table 4. Filamentous fungi and yeasts isolated from the rocks of Niedźwiedzia Cave in Kletno (debris sampling procedure).

\begin{tabular}{|c|c|c|c|c|}
\hline $\begin{array}{l}\text { Location of } \\
\text { measurement }\end{array}$ & Taxa & $\begin{array}{l}\text { CFU / } \\
25 \text { rocks }\end{array}$ & $\begin{array}{l}\text { Total CFU / } \\
25 \text { rocks }\end{array}$ & [\%] \\
\hline \multirow{5}{*}{ Lion's Hall } & Aspergillus niger group & 2 & \multirow{5}{*}{28} & 7.1 \\
\hline & Fusarium oxysporum Schltdl. & 1 & & 3.6 \\
\hline & $\begin{array}{l}\text { Penicillium chrysogenum } \\
\text { Westling }\end{array}$ & 9 & & 32.1 \\
\hline & Rhizopus stolonifer (Ehrenb.) Vuill & 15 & & 53.6 \\
\hline & $\begin{array}{l}\text { Rhodotorula rubra (Schimon) F.C. } \\
\text { Harrison }\end{array}$ & 1 & & 3.6 \\
\hline \multirow{6}{*}{$\begin{array}{l}\text { The Palace } \\
\text { Hall }\end{array}$} & Aspergillus niger group & 3 & \multirow{6}{*}{26} & 11.5 \\
\hline & Mucor mucedo de Bary \& Woron & 4 & & 15.4 \\
\hline & $\begin{array}{l}\text { Penicillium chrysogenum } \\
\text { Westling }\end{array}$ & 5 & & 19.2 \\
\hline & Rhizopus stolonifer (Ehrenb.) Vuill & 7 & & 26.9 \\
\hline & Trichoderma harzianum Rifai & 5 & & 19.2 \\
\hline & $\begin{array}{l}\text { Ulocladium alternariae (Cooke) } \\
\text { E.G. Simmons }\end{array}$ & 2 & & 7.7 \\
\hline \multirow{5}{*}{$\begin{array}{l}\text { Primitive } \\
\text { Man's } \\
\text { Corridor }\end{array}$} & Aspergillus niger group & 1 & \multirow{5}{*}{21} & 4.8 \\
\hline & Fusarium graminearum Schwabe & 2 & & 9.5 \\
\hline & Mucor mucedo de Bary \& Woron & 5 & & 23.8 \\
\hline & $\begin{array}{l}\text { Penicillium chrysogenum } \\
\text { Westling }\end{array}$ & 7 & & 33.3 \\
\hline & Rhizopus stolonifer (Ehrenb.) Vuill & 6 & & 28.6 \\
\hline
\end{tabular}

Table 5. Filamentous fungi and yeasts isolated from the rocks of Niedźwiedzia Cave in Kletno (swab sampling procedure).

\begin{tabular}{|c|c|c|c|c|}
\hline $\begin{array}{l}\text { Location of } \\
\text { measurement }\end{array}$ & Taxa & $\begin{array}{l}\mathrm{CFU} / \mathrm{cm} 2 \\
\text { rock }\end{array}$ & $\begin{array}{c}\text { Total CFU/ } \\
\text { cm2 rock } \\
\text { surface }\end{array}$ & [\%] \\
\hline \multirow{4}{*}{ Lion's Hall } & $\begin{array}{l}\text { Candida albicans (C.P. Robin) } \\
\text { Berkhout }\end{array}$ & $4.28 * 10^{-2}$ & \multirow{4}{*}{4.79} & 0.9 \\
\hline & $\begin{array}{l}\text { Mucor mucedo de Bary \& } \\
\text { Woron }\end{array}$ & $3.84 * 10^{-2}$ & & 0.8 \\
\hline & $\begin{array}{l}\text { Penicillium chrysogenum } \\
\text { Westling }\end{array}$ & $3.86 * 10^{-1}$ & & 8.1 \\
\hline & $\begin{array}{l}\text { Rhizopus stolonifer (Ehrenb.) } \\
\text { Vuill }\end{array}$ & 4.32 & & 90.2 \\
\hline \multirow{6}{*}{$\begin{array}{l}\text { The Palace } \\
\text { Hall }\end{array}$} & $\begin{array}{l}\text { Acremonium strictum W. } \\
\text { Gams }\end{array}$ & $1.67 * 10^{-2}$ & \multirow{6}{*}{2.69} & 0.6 \\
\hline & $\begin{array}{l}\text { Candida albicans (C.P. Robin) } \\
\text { Berkhout }\end{array}$ & $9.95 * 10^{-2}$ & & 3.7 \\
\hline & $\begin{array}{l}\text { Mucor mucedo de Bary \& } \\
\text { Woron }\end{array}$ & $3.65 * 10^{-2}$ & & 1.4 \\
\hline & $\begin{array}{l}\text { Rhizopus stolonifer (Ehrenb.) } \\
\text { Vuill }\end{array}$ & 2.21 & & 82.1 \\
\hline & Trichoderma harzianum Rifai & $2.34 * 10^{-2}$ & & 0.9 \\
\hline & $\begin{array}{l}\text { Ulocladium alternariae } \\
\text { (Cooke) E.G. Simmons }\end{array}$ & $3.07 * 10^{-1}$ & & 11.4 \\
\hline \multirow{3}{*}{$\begin{array}{l}\text { Primitive } \\
\text { Man's } \\
\text { Corridor }\end{array}$} & $\begin{array}{l}\text { Mucor mucedo de Bary \& } \\
\text { Woron }\end{array}$ & $1.79^{-2}$ & \multirow{3}{*}{1.62} & 1.1 \\
\hline & $\begin{array}{l}\text { Penicillium chrysogenum } \\
\text { Westling }\end{array}$ & $2.71 * 10^{-1}$ & & 16.7 \\
\hline & $\begin{array}{l}\text { Rhizopus stolonifer (Ehrenb.) } \\
\text { Vuill }\end{array}$ & 1.33 & & 82.2 \\
\hline
\end{tabular}

Table 6. Filamentous fungi isolated from the rocks of Niedźwiedzia Cave in Kletno (rinse sampling procedure).

\begin{tabular}{|l|l|}
\hline \multirow{4}{*}{ Location of measurement } & \multicolumn{1}{|c}{ Taxa } \\
\hline \multirow{5}{*}{ Lion's Hall } & Acremonium strictum W. Gams \\
\cline { 2 - 3 } The Palace Hall & Aspergillus niger group \\
\cline { 2 - 3 } & Penicillium chrysogenum Westling \\
\cline { 2 - 2 } & Rhizopus stolonifer (Ehrenb.) Vuill \\
\hline \multirow{5}{*}{ Primitive Man's Corridor } & Aspergillus niger group \\
\cline { 2 - 2 } & Mucor mucedo de Bary \& Woron \\
\cline { 2 - 2 } & Penicillium chrysogenum Westling \\
\cline { 2 - 2 } & Rhizopus stolonifer (Ehrenb.) Vuill \\
\cline { 2 - 2 } & Trichoderma harzianum Rifai \\
\hline & Mucor mucedo de Bary \& Woron \\
\cline { 2 - 2 } & Penicillium chrysogenum Westling \\
\cline { 2 - 2 } & Rhizopus stolonifer (Ehrenb.) Vuill \\
\hline &
\end{tabular}


is a fast growing fungus developing on in broad range of temperatures and relative humidities (Nishijima et al., 1990). In humans it can cause mucormycosis of lungs, sinuses and generalized mucormycosis (Adamski et al., 2008a). Rhizopus stolonifer is a fungus commonly present in the air. It has been confirmed by a mycological study of indoor air (Ogórek, 2011; Ogórek et al., 2011a, b) as well as the air analyses from the mountain trails of the Snieżnik Massif, in which Niedźwiedzia Cave is located (Ogórek et al., 2012).

Microbiological evaluation of the rocks in Niedźwiedzia Cave was performed using three methods. Most of the species of fungi were isolated using debris sampling procedure and the least species by rinse sampling procedure (Table 4, 5, 6). Differences in number of fungi species on the rocks may be caused by imprecision of the testing methods used or by the difference in the samples, which were collected in each location. Therefore, the microbiological evaluation of the rocks should be accomplished using several methods.

\section{ACKNOWLEDGEMENTS}

We wish to thank the Supervisory Board and the Management Board of Niedźwiedzia Cave, and in particular Mr. Artur Sawicki for his help in the study.

\section{REFERENCES}

Adamski Z., Henke K., Zawirska A., Kubisiak-Rzepczyk H., 2008a - Grzybice narzadowe. In: Baran E. (Eds.), Mikologia - co nowego? Cornetis, Wrocław, 189-202 p.

Adamski Z., Henke K., Zawirska A., Kubisiak-Rzepczyk H., 2008b - Grzybice błon śluzowych. In: Baran E. (Eds.), Mikologia - co nowego? Cornetis, Wrocław, 174-187 p.

Adamski Z., Henke K., Zawirska A., Kubisiak-Rzepczyk H., 2008c - Rola grzybów w etiopatogenezie chorób alergicznych. In: Baran E. (Eds.), Mikologia - co nowego? Cornetis, Wrocław, 30-42 p.

Agrios G.N., 1997 - Plant Pathology. Fourth edition. Academic Press, 283-286 p.

Barton H.A., Northup D.E., 2007 - Geomicrobiology in cave environments: past current and future perspectives. Journal of Cave and Karst Studies, 69: 163-178.

Bastian F., Jurado V., Nováková A., Alabouvette C., SaizJimenez C., 2010 - The microbiology of Lascaux Cave. Microbiology, 156: 644-652. http://dx.doi.org/10.1099/mic.0.036160-0

Bieroński J., Socha P., Stefaniak K., 2007 - Jaskinie masywu Śnieżnika Kłodzkiego. Materiały 41. Sympozjum Speleologicznego, Kletno, 9-16.

Cwalina B., 2008 - Biodeterioration of concrete. Architecture Civil Engineering Environment, 4: 133-140.

Docampo S., Trigo M.M., Recio M., Melgar M., GarcíaSánchez J., Cabezudo B., 2011 - Fungal spore content of the atmosphere of the Cave of Nerja (southern Spain): Diversity and origin. Science of the Total Environment, 409: 835-843.

http://dx.doi.org/10.1016/j.scitotenv.2010.10.048

Ellis M.B., 1971 - Dematiaceous Hyphomycetes. Commonwealth Mycological Institute, Kew, Surrey.

Gu J.D., 2003 - Microbiological deterioration and degradation of synthetic polymeric materials: recent research advances. International Biodeterioration and Biodegradation, 52: 69-91.

http://dx.doi.org/10.1016/S0964-8305(02)00177-4
Gu J.D., Ford T.E., Berke N.S., Mitchell R., 1998 Biodeterioration of concrete by the fungus Fusarium. International Biodeterioration and Biodegradation, 41: 101-109.

http://dx.doi.org/10.1016/S0964-8305(98)00034-1

Gunde-Cimerman N., Zalar P., Jeram S., 1998 - Mycoflora of cave cricket Troglophilus neglectus cadavers. Mycopathologia, 141: 111-114.

http://dx.doi.org/10.1023/A:1006947524503

Hoyos M., Soler V., Canãveras J.C., Sánchez-Moral S., Sanz-Rubio E., 1998 - Microclimatic characterization of a karstic cave: human impact on microenvironmental parameters of a prehistoric rock art cave (Candamo Cave, northern Spain). Environmental Geology, 33: 231-242. http://dx.doi.org/10.1007/s002540050242

Jurado V., Laiz L., Rodriguez-Nava V., Boiron P., Hermosin B., Sanchez-Moral S., Saiz-Jimenez C., 2010 - Pathogenic and opportunistic microorganisms in caves. International Journal of Speleology, 39: 15-24. http://dx.doi.org/10.5038/1827-806X.39.1.2

Kaiser K., 2005 - Zalecenia normatywne dla systemów wentylacji $i$ klimatyzacji $w$ szpitalach cz.1. Technika Chłodnicza i Klimatyzacyjna, 3: 99-106.

Kubátová A., Dvorák L., 2005 - Entomopathogenic fungi associated with insect hibernating in underground shelters. Czech Mycology, 57: 221-237.

Li X.S., Arai H., Shimoda I., Kuraishi H., Katayama Y., 2008 - Enumeration of sulfuroxidizing microorganisms on deteriorating stone of the Angkor monuments, Cambodia. Microbes and Environments, 23: 293-298. http://dx.doi.org/10.1264/jsme2.ME08521

Nieves-Rivera Á.M., Santos-Flores C.J., Dugan F.M., Miller T.E., 2009 - Guanophilic fungi in three caves of southwestern Puerto Rico. International Journal of Speleology, 38: 61-70. http://dx.doi.org/10.5038/1827-806X.38.1.7

Nishijima W.T., Ebersole S., Fernández J.A., 1990 Factors influencing development of postharvest incidence of Rhizopus soft rot of papaya. Acta Horticulturae, 269: 495-502.

Nováková A., 2009 - Microscopic fungi isolated from the Domica Cave system (Slovak Karst National Park, Slovakia). A review. International Journal of Speleology, 38: 71-82. http:/ / dx.doi.org/10.5038/1827-806X.38.1.8

Ogórek R., 2011 - Analiza mikologiczna powietrza wybranych pomieszczen użytku publicznego (The mycological analysis of air in selected public rosom). Episteme, II (12): 187-194.

Ogórek R., 2012 - Mycological air pollutions in Gold Mine (Gertruda's Adit) in Złoty Stok. Proceedings of the $36^{\text {th }}$ Conference of Agricultural Students and Veterinary Medicine with International Participation. Serbia, Nowy Sad, 36: 100-107.

Ogórek R., Kalinowska K., Pląskowska E., Baran E., Matkowski K., 2011a - Zanieczyszczenia powietrza grzybami na różnych podłożach hodowlanych $w$ wybranych pomieszczeniach kliniki dermatologicznej. Część 2. (Mycological air pollutions on different culture mediums in selected rooms of Dermatology Department. Part II). Medical Mycology, 18: 83-90.

Ogórek R., Pląskowska E., Kalinowska K., Fornalczyk P., Misztal A., Budziak J., 2011b - The analysis of mycological air pollution in selected rooms of student hostess. Medical Mycology, 18: 201-210.

Ogórek R., Lejman A., Pląskowska E., Bartnicki M., 2012 - Fungi in the mountain trails of the Śnieżnik Massie. Medical Mycology, 19: 57-62

Pflitsch A., Piasecki J., 2003 - Detection of an airflow system in Niedzwiedzia (Bear) Cave, Kletno, Poland. Journal of Cave and Karst Studies, 65: 160-173. 
Poulson T.L., White W.B., 1969 - The cave environment. Science, 165: 971-981.

http://dx.doi.org/10.1126/science.165.3897.971

Pulina M., 1996 - Jaskinie Sudetów. Polskie Towarzystwo Nauk o Ziemi, Warszawa, 202 p.

Pulina M., 1970 - Wstępne wyniki badań nad środowiskiem geograficznym Jaskini Niedźwiedziej. Acta Universitatis Wratislaviensis 127, Studia Geograficzne, 14: 5-37.

Pulina M., 1989 - Historia odkrycia $i$ badań. In: Jahn A., Kozłowski S., Wiszniewska T. (Eds.), Jaskinia Niedźwiedzia w Kletnie. Badania i udostępnianie. Ossolineum, Wrocław-Warszawa, 11-20 p.

Raper K.B., Fennell D.I., 1965 - The genus Aspergillus. Willims and Wilkins Company, Baltimore.

Raper K.B., Thom C., 1968 - A manual of the Penicillia. Hafner Publishing Company, New York.
Voyroni S., Lazzarii A., Riccucci M., Calvini M., Varese G.C., 2011 - First mycological investigation on Italian bats. Hystrix, the Italian Journal of Mammalogy, 22 (1): 189-197.

Wang W., Ma X., Ma Y., Mao L., Wu F., Ma X., An L., Feng H., 2010 - Seasonal dynamice of airborne fungi in different caves of the Mogao Grottoes, Dunhuang, China. International Biodeterioration and Biodegradation, 64: 461-466.

http://dx.doi.org/10.1016/j.ibiod.2010.05.005

Wiszniowska T., 1967 - Nowe znalezisko paleontologiczne $w$ Sudetach. Przegląd Zoologiczny, 11: 430-433.

Wiszniowska T., 1989 - Kopalne szczatki zwierzęce. In: Jahn A., Kozłowski S., Wiszniewska T. (Eds.), Jaskinia Niedźwiedzia w Kletnie. Badania i udostępnianie. Ossolineum, Wrocław-Warszawa, 255-279 p. 